\title{
Metaphysealisan rögzülő szárral végzett csípőizületi totál endoprotézis rövid távú eredményei Klinikánkon
}

\author{
DR. ANTAL HUNOR, DR. VERMES CSABA, DR. THAN PÉTER
}

\section{ÖSSZEFOGLALÁS}

A szerzők 26, rövid szárú csípőprotézis beültetésével szerzett tapasztalataikról számolnak be. A betegek közül 13 férfit és 9 nőt operáltak. Négy esetben végeztek mindkét oldali protézisbeültetést. Tíz esetben jobb, 16 esetben bal oldali csípőt operáltak. Az átlagos utánkövetési idő 16,5 hónap volt. A Harris Hip Score érték átlaga 56,34-ről 98,92-re, az SF-36 átlaga 89,96-ról 100,69-ra nőtt. Egy esetben volt a közvetlen posztoperatív szakban protézis luxatio, amely konzervatív kezelésre gyógyult. Egy esetben észleltek intraoperatív femur infractiót, amelyet elláttak. Szeptikus szövődmény nem volt. Az utánkövetés során aszeptikus protézislazulást nem észleltek. Több esetben dysplasiás betegeket operáltak, ezért ezek ellátása fokozott figyelmet igényelt.

\section{Kulcsszavak: $\quad$ Arthroplastica; Csípöprotézis; Csontállomány; Femur; Protézis szár;}

H. Antal, Cs. Vermes, P. Than: Short term results of total hip prostheses with metaphyseal stem anchorage at our clinic

The authors report about their experience with 26 short stem hip prostheses. They treated 13 men and 9 women with this implant. Bilateral prosthesis implantation was performed in 4 cases. They operated 10 left and 16 right hips. The follow-up period was 16.5 months on the average. The average Harris Hip Score increased from 56.34 to 98.92 and the average SF-36 from 89.96 to 100.69 . There was one prosthesis dislocation in the immediate postoperative period which was treated in a conservative manner. Intra-operative femur crack occurred in one case which was treated surgically at the same time. There was neither septic complication, nor aseptic loosening during the follow-up period. Patients with dysplastic hips were operated on in several cases, which required special attention.

Keywords: $\quad$ Arthroplasty, replacement, hip-Methods; Bone density; Femur - Physiopathology/Surgery; Hip prosthesis; Prosthesis design; 


\section{BEVEZETÉS}

Napjainkban egyre fiatalabb életkorban kerülnek beültetésre protézisek, ugyanakkor ezzel párhuzamosan az implantációk száma nő (3). Ennek oka, hogy a klinikai eredmények kitűnőek, és a protézisek élettartama is egyre hosszabb. Ebből fakadóan a protézis-revíziós mútétekre is gyakrabban kerül sor. Ezeknél a mútéteknél különösen fontos szempont a csontállomány állapota. Az utóbbi években számos, cement nélküli, metaphysealisan rögzülő csípő protézis szár került forgalomba fiatal betegek számára, melyek célja a csontállomány megőrzése $(5,6,8,12,13)$. Osteo-denzitometriás mérésekkel igazolható, hogy a rövid protézis szárak a környező csontállományban csonttömeg növekedést eredményeznek $(2,13)$. A fiziológiásabb terhelésátvitel csökkenti a femur proximalis részének csont-reszorpcióját (stress-shielding-et), ezáltal az aszeptikus lazulás kockázatát. Femur deformitások esetén a reszekció megválasztása különösen fontos. Foelkemeier és munkatársai háromféle reszekciós magasság esetén vizsgálták a Metha ${ }^{\mathrm{TM}}$ szár körüli csontfeszülés mintázatát (strain-mintázatot). Méréseiket múcsonton végezték, a mú combcsontokat háromféle reszekciós magasságban fürészelték le, ezután Metha ${ }^{\mathrm{TM}}$ szárat ültettek be. Tíz helyen mérték a femurokon a csontfeszülést, adott terhelés alatt: megfelelő csontfeszülésmintázatot kaptak múcsonton akkor is, ha mélyebb reszekciót végeztek a combnyakon, de volt még elegendő corticalis csontgyürü (3). A csípőízület forgáspontja és a trochanter maior közötti távolság (femur offset) mértékét rövid protézis szárak esetén befolyásolja a combnyakon végzett reszekció magassága. A femoralis offset növekedése csípőprotézis beültetése után általános jelenség a különböző szártípusoknál. Jobb mozgástartományt, jobb funkcionális eredményt, stabilitást és kevesebb kopást eredményez. Ezért a mútét előttivel megegyező, vagy nagyobb offset az ajánlott (1).

Gómez-Garcia és munkatársai 20 gyártó 42 rövid szárú protézisét csoportosította 3 csoportba és 15 családba (I. táblázat) (4). Valójában nincsen konszenzus arról, hogy mit jelent a rövid protézis szár. Stulbergh szerint a rövid szárú protézisnek rövidebbnek kell lennie, mint 120 mm. Ám ugyanaz a szárhossz, ami egy magas betegnél rövid szárnak számít, egy alacsonynál már nem biztos, hogy rövid lesz (13).

Általánosságban a következő szempontokat kell figyelembe venni:

1) azt az anatómiai régiót, amiben elhelyezkednek,

2) az alapvető geometriai tervezést,

3) a fő erő-átviteli zónákat,

4) a szükséges femur-reszekció szintjét,

5) a beültetés során alkalmazott tájékozódási tengelyeket (4).

A rövid protézisszárak két legfontosabb előnye, hogy nem csak a csontot őrzik meg, hanem a proximalis femur leépülését kevésbé idézik elő, mivel a fej-metaphysis határon rögzülnek.

A fentieken kívül leírnak még előnyöket, egyes érvek ezek közül vitathatóak:

1) A rövid szár jobban adaptálható az anatómiailag különböző femur nyak típusokhoz.

2) Jobban feltámaszkodnak az Adam-íven.

3) Jobban illeszthetőek meglévő femurdeformitásokhoz.

4) Könnyebb a revíziójuk.

5) Elülső feltárásból könnyebb beültetni, mint a standard szárakat.

6) Csökkenti a stress-shielding esélyét.

7) Kevesebb intraoperatív vérzés várható.

8) Kevesebb múszerkészlet szükséges,

9) ez elősegíti, hogy a műszerkészlet kevesebbe kerüljön.

10) Csökkenti a posztoperatív rehabilitációs időt (4). 
I. táblázat A rövid szárak típusai (Gómez-Garcia és munkatársai, 2016)

\begin{tabular}{|l|l|}
\hline \multicolumn{1}{|c|}{ Típus } & \multicolumn{1}{c}{ Család } \\
\hline A & Felszínpótló \\
\hline B & Nyak gallérral \\
\hline & Nyak gallérral és extramedullaris támasztékkal \\
\hline & Ultrarövid nyak, gallér nélkül \\
\hline & Ultrarövid szár, gallér nélkül \\
\hline & Ultrarövid szár, gallér és extramedullaris támaszték nélkül \\
\hline C & Ívelt, gallérral \\
\hline & Ívelt, gallér nélkül („C", vagy banán alakú) \\
\hline & Ívelt, gallér nélkül, hajlított heggyel \\
\hline & Egyenes ék, gallér nélkül \\
\hline & Egyenes, strukturált, gallér nélkül \\
\hline & Egyenes, kúpos, nem strukturált, gallér nélkül \\
\hline & Ívelt, gallér nélkül, ék alakú, kúpos (metaphysisben rögzülő) \\
\hline & Egyes geometriai tervezések gallérral, vagy gallér nélkül \\
\hline & Egyedi gyártású rövid szárú protézisek \\
\hline
\end{tabular}

\section{ANYAG ÉS MÓDSZER}

2013. január 1. és 2015. december 31. között végzett rövid szárú totál csípőprotézis beültetések eredményeit vizsgáltuk prospektív módon. Metha ${ }^{\mathrm{TM}}$ (Aesculap AG, Tuttlingen, Németország) és Nanos ${ }^{\mathrm{TM}}$ (Smith \& Nephew, Memphis, USA) protéziseket ültettünk be (1. ábra). Mindkét típus úgynevezett metaphysealisan rögzülő rövid szárú csípőprotézis, amelyek megfelelő proximalis terhelésátvitelt biztosítanak.

Mútéteink során hatvan év alatti, munkaképes betegeket operáltunk, akiknél a későbbiekben várhatóan revíziós mútétre lesz szükség. Kontraindikációt jelentett a 100 kg-nál magasabb testtömeg, a súlyos varus/valgus deformitás, súlyos osteoporosis.

Összesen 22 beteget operáltunk, ebből 4 esetben mindkét oldalon történt mútét, így összesen 26 csípőprotézist ültettünk be (13 férfi, 9 nó). 12 esetben jobb, 14 esetben bal oldali mútétet végeztünk. 22 Metha $^{\mathrm{TM}}$ és 4 NANOS $^{\mathrm{TM}}$ protézist implantáltunk. A betegek átlagéletkora a mútét időpontjában 43,46 év volt (18-58 év). Az átlagos utánkövetési idő 16,5 hónap volt (6-28 hónap).

A betegek eredményeinek értékeléséhez a Harris Hip Score-t és az SF-36 kérdőívet használtuk, amelyeket közvetlenül a mútét előtt és a mütét után 6 hónappal felvettünk. Röntgenfelvételt a mútétek előtt közvetlenül, és mútét után 3, 6 és 12 hónappal készítettünk.

A mútéteket hat operatőr végezte. A betegeket hanyatt fekvő helyzetben, anterolateralis feltárásból operáltuk. Antibiotikus és antitrombotikus profilaxisban részesültek. A mútét után 6 hétig részterhelést végeztek a betegek. 


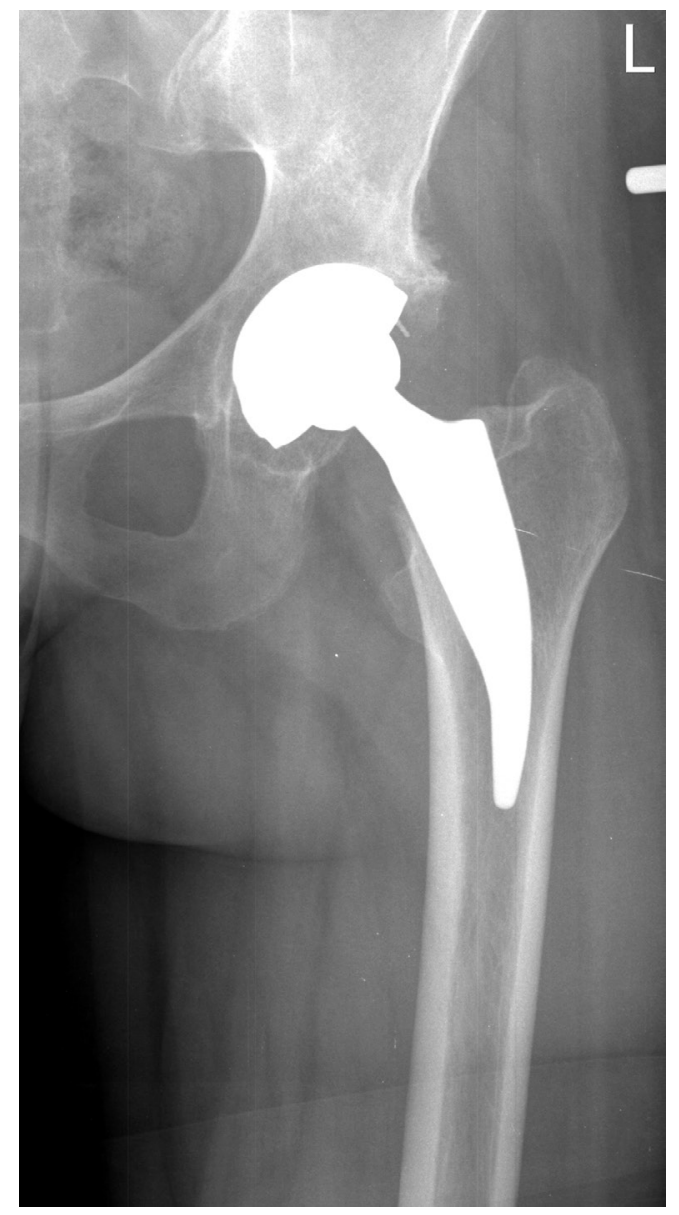

1. ábra 37-éves nöbeteg kontroll röntgenfelvétele (Metha)

\section{EREDMÉNYEK}

A 26 csípőből 6 eset volt primer coxarthrosis, 12 esetben operáltunk combfej necrosist (ezek közül 7 eset volt idiopathiás, 3 esetben autoimmun betegség talaján alakult ki, 1 esetben kemoterápia okozta a combfej elhalást, egy necrosis medialis combnyaktörés miatt alakult ki). Nyolc esetben operáltunk dysplasiás csípőízületet, ebből 3 esetben korábban femur osteotomia történt.

A 3, 6 és 12 hónapos korban készült röntgenfelvételeken aszeptikus kilazulást nem találtunk, erre utaló klinikai jelet sem észleltünk. A HHS értékek átlaga a mútét előtt 56,34 $( \pm 13,18)$ volt, amely a mútét után fél évvel mérve 98,92 $( \pm 2,96)$ lett (2. ábra). Az SF-36 átlagértéke a mútét előtt $89,96( \pm 13,99)$ volt, amely a mütét után $100,69( \pm 3,27)$ értékre változott (3. ábra). Mindkét paraméter változása statisztikailag szignifikánsnak bizonyult $(p<0,001)$. Egyik beteg sem panaszkodott posztoperatív combfájdalomról. Egy esetben észleltünk intraoperatív femur infrakciót, amelyet a műtét során Atlas-kábellel elláttunk. Egy esetben történt a közvetlen posztoperatív időszakban protézis ficam, amelyet reponáltunk és konzervatív úton gyógyult, ismételt ficam nem jelentkezett. Ez a két szövődmény ugyanazon a betegen jelentkezett, aki mindkét oldali csípőficammal született (4. ábra). Fél és egy évvel a mútétei után a HHS értékei 98 és 100 pont voltak. 


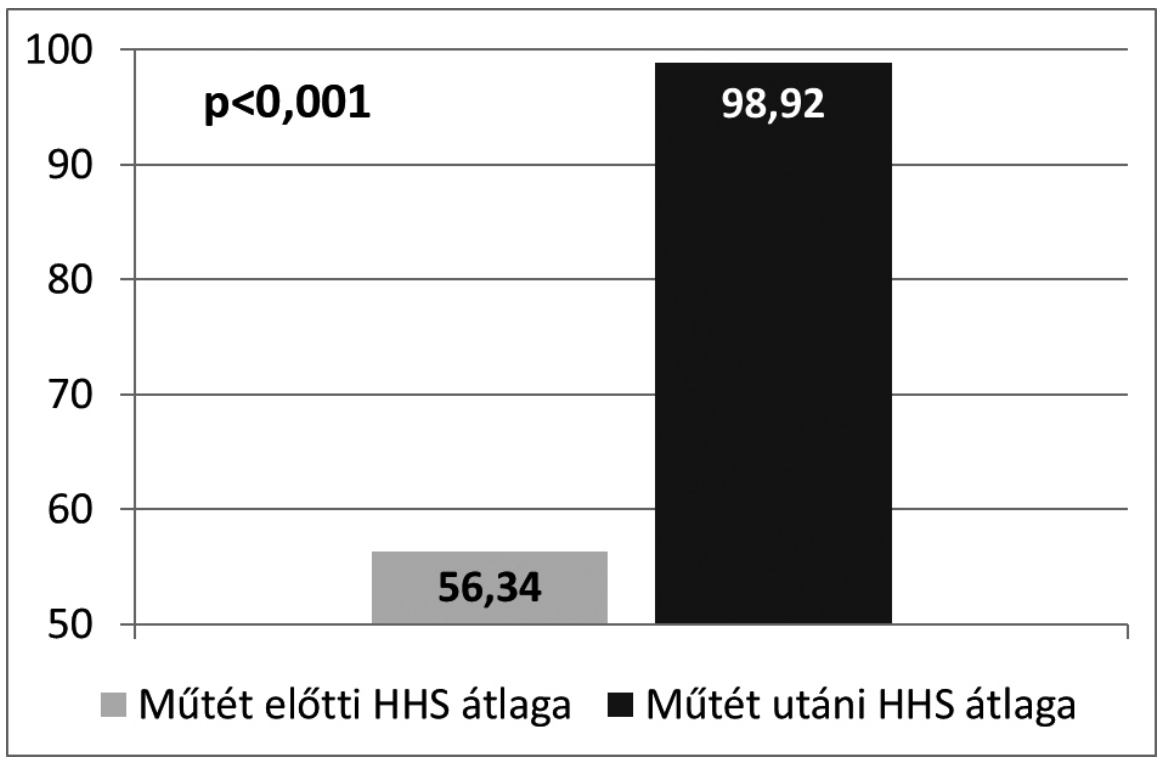

2. ábra HHS értékek átlaga

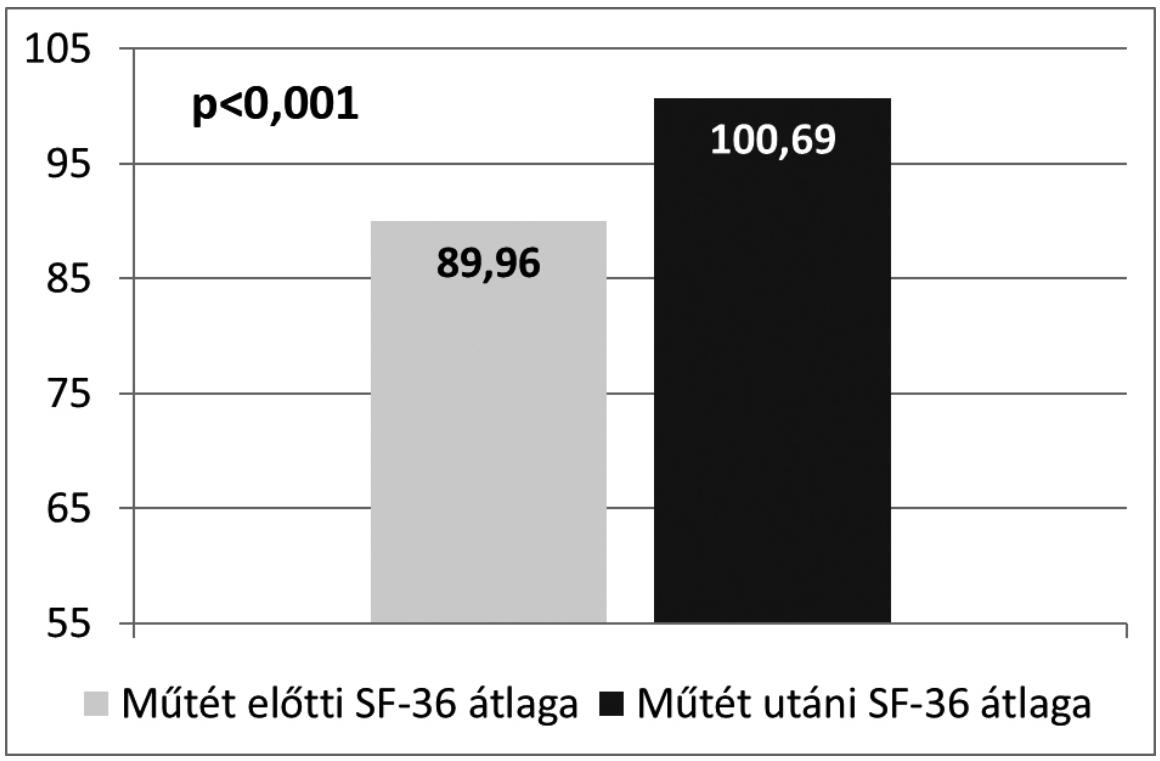

3. ábra SF-36 értékek átlaga 


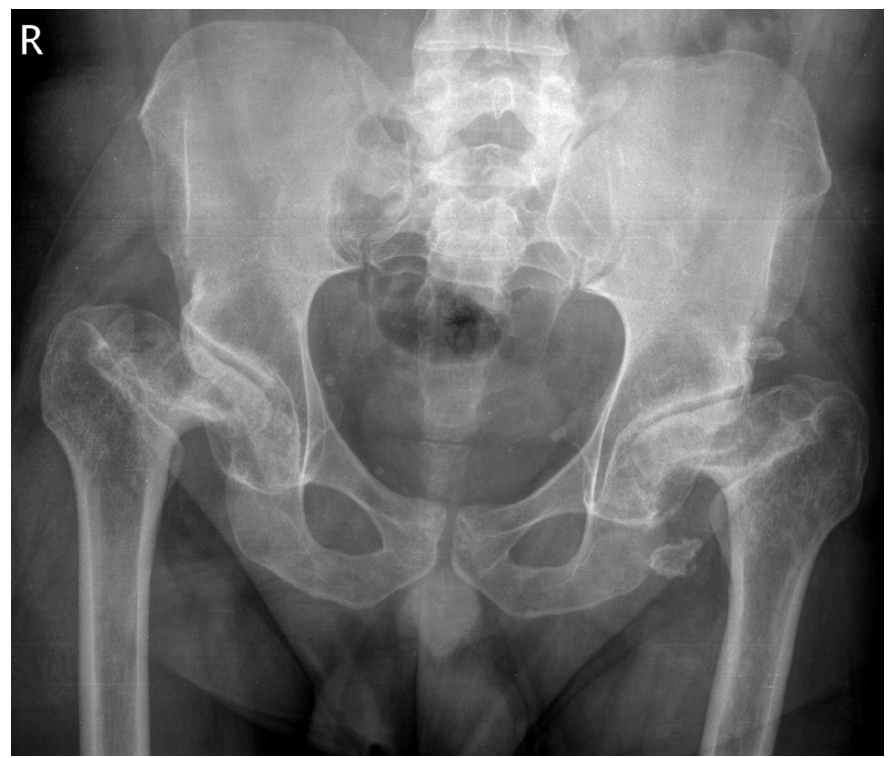

4. a ábra

39-éves férfibeteg preoperatív röntgenképe. Mindkét oldali dysplasiás coxarthrosis

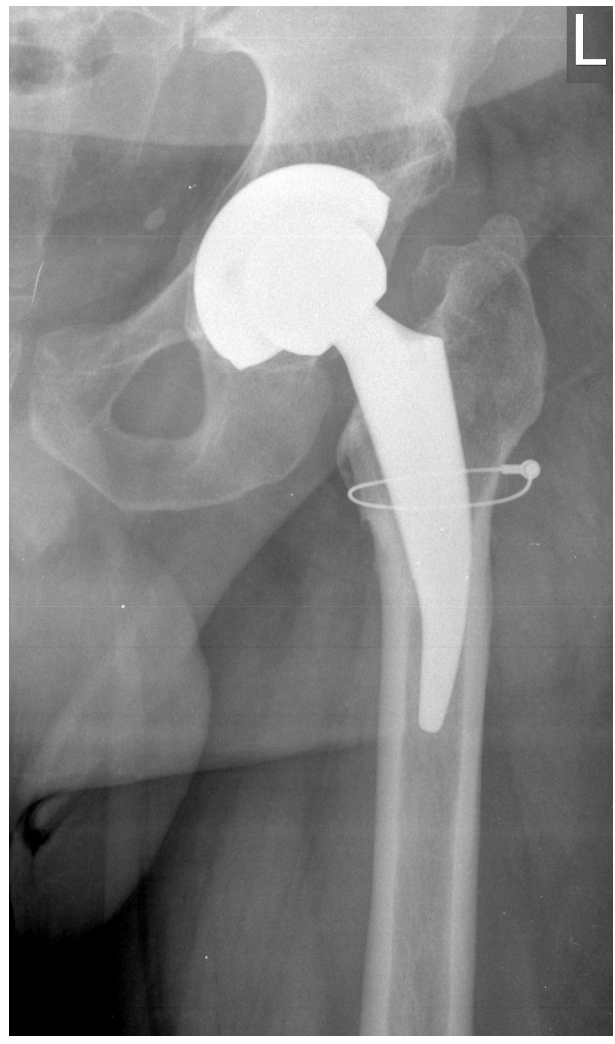

4. bábra

Posztoperativ röntgenkép. A beültetése során észlelt femur fissura miatt, cerclage drótos szintézis történt 


\section{MEGBESZÉLÉS}

Az elmúlt harminc évben a cement nélküli protézisek nagy fejlődésen mentek keresztül. Fontos lehetőséget jelentenek a fiatalabb korosztály mútéti ellátása során, de az indikációs határokat nem lehet túlfeszíteni $(7,11)$.

A magyar nyelvú irodalomban eddig egy közlemény jelent meg, Tóth és munkatársai részéről. 2009-ben közölték 33 Proxima ${ }^{T M}$ (DePuy, Leeds, U. K.) típusú protézis eredményeit, ahol a HHS érték a mútét előtti 39-ről 6 hónappal később 77-re, majd egy év múlva 88-ra emelkedett (16).

A HHS és az SF-36 értékek átlaga szignifikáns emelkedést mutattak vizsgálatunk során. Bár összesen négy betegnél implantáltunk NANOS $^{\mathrm{TM}}$ szárat, nem találtunk a klinikai eredményekben különbséget a Metha ${ }^{\mathrm{TM}}$ és NANOS ${ }^{\mathrm{TM}}$ szárak között.

Brinkmann és munkatársai sem találtak szignifikáns különbséget a Metha ${ }^{\mathrm{TM}}$ és NANOS $^{\mathrm{TM}}$ szárak klinikailag releváns migrációja és a körülöttük lévő csontdenzitás értéke között. Mindkét szár esetén szignifikáns javulást mutatott a HHS érték (NANOS ${ }^{\mathrm{TM}}$ 96,5, Metha $^{\mathrm{TM}}$ 96,2 lett mútét után 1 évvel) és a vizuális analóg skála értéke is (2). Lerch és munkatársai 25 beteget vizsgáltak, akik Mayo ${ }^{\mathrm{TM}}$ (Zimmer, Warsaw, U. S. A.), vagy Metha'M rövid szár beültetésen estek át. A HHS érték szignifikánsan, 31 ponttal emelkedett, egy szárat sem kellett revideálniuk. A DEXA-analízis során stress-shieldinget észleltek a trochenter maior területén és a vizsgálat koncentrált erőeloszlást mutatott a femur medialis részén (9). Wittenber és munkatársai Metha ${ }^{\mathrm{TM}}$ rövid szárú protézisek esetén a következőket mérték: a HHS értékek átlaga a legutolsó posztoperatív vizsgálat alkalmával 97 pont, 6,5 évvel a mútét után 100 pont volt. Combfájdalomról a betegek nem számoltak be. Az ötéves Kaplan-Meier túlélés $92 \%$ volt (17). Thorey és munkatársai 151 MethaTM rövid szárú protézist vizsgáltak, az átlagos utánkövetési idő 5,8 év volt, az átlagéletkor 55,7 év. A HHS érték 46 \pm 17 preoperatív értékről $90 \pm 5$ pontra emelkedett a legutolsó utánkövetési vizsgálatra. Egyik beteg sem panaszkodott combfájdalomra (14).

Két esetben volt szövődményünk (egy esetben intraoperatív törés, egy esetben posztoperatív protézis ficam). Nagyobb esetszámon Wittenberg és munkatársai 250 Metha $^{\text {TM }}$ rövid szárú protézist vizsgáltak prospektíven, ezeket klinikailag és radiológiailag értékelték. Az esetek $16 \%$-a volt dysplasiás. Kilenc esetben kellett revíziót alkalmazni, három esetben bakteriális fertőzés alakult ki, két esetben a szár penetrált a femuron két és három hónappal a mútét után, három esetben egy éven belül aszeptikus lazulás alakult ki (16). Egy esetben jegyeztek föl intraoperatív femoralis fissurát, amelyet cerclage dróttal láttak el (16). Thorey és munkatársai három esetben végeztek revíziót (a 151 primeren beültetett Metha ${ }^{\mathrm{TM}}$ rövid szárú protézisből): egy esetben alakult ki bakteriális fertőzés, két esetben pedig alulméretezés miatt kellett standard szárral revideálni a rövid szárat (14).

Tóth és munkatársai két periprotetikus törést mutattak be tanulmányukban. $A z$ egyik betegnél Proxima ${ }^{\circledR}$ (DePuy, Leeds, UK), másik betegnél Metha ${ }^{\circledR}$ (B. Braun Aesculap, Tuttlingen, Németország) rövid szárú protézis került beültetésre. Mindkét esetet konzervatív úton kezelték: teljes csontos átépülést és kitúnő klinikai eredményeket értek el (15).

Irodalmi adatok alapján standard száraknál magasabb az intraoperatív femurtörés kockázata. Molli és munkatársai 2011-ben közölt vizsgálatában rövid (269), és standard (389) cement nélküli szárakat hasonlítottak össze (Biomet, Warsaw, IN, USA; Zimmer, Warsaw, IN, USA; Styker, Mahwah, NJ, USA), retrospektív módon. Standard szárak esetén magasabb intraoperatív femurtörés arányt észleltek $(3,1 \%$, szemben a rövid szárak esetén $0,4 \%)$; ezeket cerclage dróttal látták el. Az átlagos utánkövetési idő 29,2 hónap volt, ezen időtartam alatt a két csoport túlélésében, HHS értékében különbség nem mutatkozott (10).

Saját eredményeink a fentiekkel megegyeznek. Vizsgálatunk azt mutatja, hogy a rövid szárú protézisek sikeresen alkalmazhatók jó és kiváló eredménnyel. Bár az utánkövetési idő rövid (1,3 év), de a túlélési arány eddig $100 \%$. Maga az implantátum a fiatal betegek körében nagy megelégedettséget eredményezett. A rövid protézisszár implantációját meg kell fontolni minden olyan fiatal beteg esetén, akiknél kontraindikáció (osteoporotikus csontvesztés, femur nyak/metaphysis necrosisa, durva deformitás) nem áll fönn. 


\section{IRODALOM}

1. Amenabar T., Marimuthu K., Hawdon G., Gildone A., McMahon S.: Total hip arthroplasty using a short-stem prosthesis: restoration of hip anatomy. J. Orthop. Surg. 2015. 23. (1): 90-94. https://doi.org/10.1177/230949901502300121

2. Brinkmann V., Radetzki F., Delank K. S., Wohlrab D., Zeh A.: A prospective randomized radiographic and dual-energy X-ray absorptiometric study of migration and bone remodelling after implantation of two modern short-stemmed femoral prosthesis. J. Orthop. Traumatol. 2015. 16. (3): 237-243. https://doi.org/10.1007/s10195-015-0335-1

3. Floerkemeier T., Gronewold J., Berner S., Olender G., Hurschler C., Windhagen H., von Levinski G.: The influence of resection height on proximal femoral strain patterns after Metha short stem hip arthroplasty: an experimental study on composite femora. Int. Orthop. 2013. 37. (3): 369-377. https://doi.org/10.1007/s00264-012-1725-0

4. Gómez-Garcia F., Fernandez-Fairen M., Espinosa-Mendoza R. L.: A proposal for the study of cementless short-stem hip prostheses. Acta Ortop. Mex. 2016. 30. (4): 204-215.

5. Gulow J., Scholz R., Freiherr von Salis-Soglio G.: Kurzschäfte in der Hüftendoprothetik. Orthopäde. 2007. 36. (4): $353-359$. https://doi.org/10.1007/s00132-007-1071-x

6. Hube R., Zaage M., Hein W., Reichel H.: Frühfunktionelle Ergebnisse einer Kurzschaftprothese des Hüftgelenks mit Metaphysär intertrochantärer Verankerung. Orthopäde. 2004. 33. (11): 1249-1258. https://doi.org/10.1007/s00132-004-0711-7

7. Jerosch J.: Ist kürzer wirklich besser? Philosophie der Kurzschaftendoprothesen Orthopäde. 2011. 40. (12): $1075-1083$. https://doi.org/10.1007/s00132-011-1848-9

8. Kircher J., Bergschmidt P., Bader R., Kluess D., Besser-Mahuzir E., Leder A., Mittelmeier W.: Die Bedeutung der Gleitpaarung beim jüngeren Endoprothesen patienten. Orthopäde. $2007 . \quad 36 . \quad$ (4): 337-346. https://doi.org/10.1007/s00132-007-1069-4

9. Lerch M., von der Haar-Tran A., Windhagen H., Behrens B. A., Wefstaedt P., Stukenborg-Colsman C. M.: Bone remodelling around the Metha short stem in total hip arthroplasty: a prospective dual-energy X-ray absorptiometry study. Int. Orthop. 2012. 36. (3): 533-538. https://doi.org/10.1007/s00264-011-1361-0

10. Molli R. G., Lombardi A. V. Jr., Berend K. R., Adams J. B., Sneller M. A.: A short tapered stem reduces intraoperative complications in primary total hip arthroplasty. Clin. Orthop. Relat. Res. 2012. 470. (2): $450-461$. https://doi.org/10.1007/s11999-011-2068-7

11. Pellengahr C. S., Fottner A., Utzschneider S., Schmitt-Sody M., Teske W., Lichtinger T., Esenwein S. A.: Zementfreie Endoprothetik des Hüftgelenks. Orthopäde. 2009. 38. (5): 461-472. https://doi.org/10.1007/s00132-009-1418-6

12. Renkawitz T., Santori F. S., Grifka J., Valverde C., Morlock M. M., Learmonth I. D.: A new short uncemented, proximally fixed anatomic femoral implant with a prominent lateral flare: design rationals and study design of an international clinical trial. BMC Musculoskel. Disord. 2008. 9: 147-152. https://doi.org/10.1186/1471-2474-9-147

13. Stulbergh S. D., Patel R. M.: The short stem: promises and pitfalls. Bone Joint J. 2013. 95-B. (11. Suppl A): 57-62. https://doi.org/10.1302/0301-620X.95B11.32936

14. Thorey F., Hoefer C., Abdi-Tabari N., Lerch M., Budde S., Windhagen H.: Clinical results of the Metha short hip stem: a perspective for younger patients? Orthop. Rev. 2013. 5. (4): e34. https://doi.org/10.4081/or.2013.e34

15. Toth K., Gality H., Gion K., Sisak K.: Conservative treatment of periprosthetic femur fractures around metaphyseal short stems - A feasible option? Trauma Case Riport, 2017. 9: 34-37. https://doi.org/10.1016/j.tcr.2017.05.009

16. Tóth K., Kellermann P., Wellinger K.: A csontállományt megtartó, metaphysealis rögzítésü cement nélküli szár beültetésével szerzett korai tapasztalataink. Magyar Traumatológia Ortopédia Kézsebészet Plasztikai Sebészet, 2009. 52. (4): $259-266$.

17. Wittenberg R. H., Steffen R., Windhagen H., Bücking P., Wilcke A.: Five-year results of a cementless short-hip-stem prosthesis. Orthop. Rev. 2013. 5. (1): e4. https://doi.org/10.4081/or.2013.e4

\section{Dr. Antal Hunor}

PTE Ortopédiai Klinika

7632 Pécs, Akác u. 1. 